Tack F.M., Verloo M.G., 1996. Metal contents in stinging nettle (Urtica dioica L.) as affected by soil characteristics.. The Science of the Total Environment 192, 31-39.

The original publication is available at http://www.elsevier.com/

\title{
Metal contents in stinging nettle (Urtica dioica L.) as affected by soil characteristics
}

\author{
F.M. Tack, M.G. Verloo \\ Laboratory of Applied Analytical Chemistry and Ecochemistry, University of Gent, Coupure \\ Links 653, B-9000 Gent, Belgium
}

\begin{abstract}
Uptake by plants is a potential pathway of metal transfer to the human food-chain. A correct quantification critically affects the outcome of environmental risk assessment. Using data of soils and plants (Urtica dioica L.) from 382 locations north-east of Ghent, the relation between soil characteristics (clay content, organic carbon content, $\mathrm{CEC}$, soil $\mathrm{pH}$ and total metal content) and plant concentrations of metals was studied. Plant metal contents of $\mathrm{Zn}$ and Mn varied widely for low values of clay $(<10 \%), \mathrm{CEC}\left(<15 \mathrm{cmol}_{\mathrm{c}} \mathrm{kg}^{-1}\right)$ and organic carbon $(<3 \%)$ in the soil, and were lower and less variable for higher values of these soil parameters. No systematic trend was observed as a function of soil $\mathrm{pH}$. For other metals $(\mathrm{Cd}, \mathrm{Co}, \mathrm{Cr}, \mathrm{Cu}$, $\mathrm{Fe}, \mathrm{Ni}, \mathrm{Pb}$ ), ranges in plant metal concentrations were not affected by the soil characteristics studied. Bulk soil parameters do not constitute sufficient information for a precise prediction of plant metal contents in the field.
\end{abstract}

Keywords: Heavy metals; Plant uptake; Soil-plant relationship

\section{Introduction}

Uptake by plants is a potential pathway of metal transfer to the human food-chain. Soil characteristics as $\mathrm{pH}$, cation exchange capacity (CEC), soil texture and organic carbon content influence the uptake of metals in a soil. Metal uptake, moreover, is plant-species dependent and is influenced by interactions of the elements in the soil solution [1] [2] [3].

Newly developed quality criteria for metals in soils are increasingly based on risk assessment studies [4]. Plant uptake of metals from soils is one of the pathways considered in models aimed at assessing the hazard of chemical contaminants in soil [5] [6].

In 1979 and 1980, a survey on soil and plant metal contents was undertaken in an approx. $630 \mathrm{~km}^{2}$-area between the cities of Gent and Antwerpen (Fig. 1) [7]. Soil characteristics and metal concentrations in soils and plants (stinging nettle - Urtica dioica L. and/or grass - Poa $s p$.) from 494 sampling points were determined. At 382 locations, stinging nettle was sampled. We studied these field data to evaluate the relation between bulk soil properties as clay content, organic carbon content, cation exchange capacity, $\mathrm{pH}$, soil metal content, and metal contents in stinging nettle. 


\section{Experimental}

Soil and plant (stinging nettle, Urtica dioica L.) analysis data from the region between Ghent and Antwerp (Fig. 1) were used for this study [7]. Summary statistics of the data are given in Table 1.

The sampling points mostly were selected to be situated in a grid of $1 \mathrm{~km}^{2}$ and included agricultural land, pasture land and forest soils. Points in private gardens or disturbed locations were not sampled. At the selected sampling points, 20 samples from 0-20 cm depth were taken within a radius of $20 \mathrm{~m}$ with a core sampler and combined. At the same time as the soil sampling, stem and leaves of plants were collected. In $90 \%$ of the sampling points, stinging nettle was available for sampling [7].

The soil samples were dried at $60^{\circ} \mathrm{C}$, ground and passed through a $2 \mathrm{~mm}$ sieve. Excessive dust was removed from the plant material, but the plants were not washed. After drying at $60^{\circ} \mathrm{C}$, the plant material was ground in a plant mill and stored in glass bottles for analysis.

Soil $\mathrm{pH}$ was measured in a 1:5 soil to water suspension after 24 hours. Soil organic carbon was determined by the method of Walkley-Black [8]. Cation exchange capacity (CEC) was determined with the ammonium acetate method. The exchange complex is saturated with ammonium. Ammonium is then displaced from the exchange complex with $\mathrm{KCl}$ solution and determined by titration [9].

Soil clay contents were derived from the database "AARDEWERK" that contains data about 13033 profiles and 69600 horizons in Belgium [10]. Using a geographic information system (ARC/Info), clay contents at the sampling points were estimated as the distant weighed average of values from data points that were (1) situated within a radius of $5 \mathrm{~km} \mathrm{(2)} \mathrm{within} \mathrm{the}$ same textural class and (3) with the same soil use (forest, agricultural land or pasture).

Soil total contents are aqua regia extractable contents [11]. Standard deviations on a triplicate analysis of a soil sample were: $0.7 \mathrm{mg} \mathrm{kg}^{-1}$ for Cd at $9.2 \mathrm{mg} \mathrm{kg}^{-1}, 9 \mathrm{mg} \mathrm{kg}^{-1}$ for $\mathrm{Cu}$ at $100 \mathrm{mg} \mathrm{kg}^{-1}, 1 \mathrm{mg} \mathrm{kg}^{-1}$ for Co at $11 \mathrm{mg} \mathrm{kg}^{-1}, 3 \mathrm{mg} \mathrm{kg}^{-1}$ for $\mathrm{Ni}$ at $40 \mathrm{mg} \mathrm{kg}^{-1}, 12 \mathrm{mg} \mathrm{kg}^{-1}$ for $\mathrm{Pb}$ at $140 \mathrm{mg} \mathrm{kg}^{-1}$, and $75 \mathrm{mg} \mathrm{kg}^{-1}$ for $\mathrm{Zn}$ at $538 \mathrm{mg} \mathrm{kg}^{-1}$. The metal contents in the plant were determined by ICP after dry ashing [9]. Standard deviations, determined by 4 -fould analysis of selected plant samples, were typically $0.03 \mathrm{mg} \mathrm{kg}^{-1}$ for $\mathrm{Cd}, 0.3 \mathrm{mg} \mathrm{kg}^{-1}$ for Co, 0.3 $\mathrm{mg} \mathrm{kg}^{-1}$ for $\mathrm{Cr}, 0.4 \mathrm{mg} \mathrm{kg}^{-1}$ for $\mathrm{Cu}, 4 \mathrm{mg} \mathrm{kg}^{-1}$ for $\mathrm{Fe}, 23 \mathrm{mg} \mathrm{kg}^{-1}$ for $\mathrm{Mn}, 0.4 \mathrm{mg} \mathrm{kg}^{-1}$ for $\mathrm{Ni}$, $0.2 \mathrm{mg} \mathrm{kg}^{-1}$ for $\mathrm{Pb}$, and $2 \mathrm{mg} \mathrm{kg}^{-1}$ for $\mathrm{Zn}$.

\section{Results and discussion}

\subsection{Scatterplots of the data}

Fig. 2 presents scatterplots for $\mathrm{Zn}$ in the plant samples (Urtica dioica L.) versus soil clay content, organic carbon content, $\mathrm{pH}, \mathrm{CEC}$ and total soil $\mathrm{Zn}$. On the graph, datapoints were distinguished according to the sum of $3 \times \%$ clay and $10 \times \%$ organic carbon in the corresponding soil.

Wide ranges in plant metal contents are observed for low clay content, organic carbon content, $\mathrm{CEC}$ and total $\mathrm{Zn}$ in the soil. For a higher value of these soil parameters, the metal concentrations in stinging nettle were generally lower and restricted within a more narrow range. It appears that these soil characteristics do not decisively influence the metal concentrations in the plant, as plant concentrations vary randomly in a wide range for low values of these soil parameters. When present at higher levels $( \pm 10 \%$ for clay and $\pm 3 \%$ for organic carbon), clay and organic carbon seem to control metal uptake, since the range of 
plant metal content is restricted to lower values and within a more narrow range. This illustrates the control these factors exert on the soil solution. The presence of clay minerals and organic material decrease the mobility and hence the plant availability of metals $[12][13][14][15]$. These soil constituents appear to 'protect' the plant from taking up larger amounts of trace metals.

Despite very high Zn-contents in some soils, metal uptake was low. These soils were from sites along the shores of the river Scheldt and in the past have been contaminated through application of dredged materials. Soils with high total contents of $\mathrm{Zn}$ were also high in clay and organic carbon that apparently controlled Zn-availability effectively.

Scatterplots of other element concentrations in relation to soil clay are presented in Fig. 3. Of the elements studied, only $\mathrm{Zn}$ and $\mathrm{Mn}$ showed this marked decrease in the range of the plant metal contents with increasing clay, organic carbon or CEC. For the other elements, the variability in plant contents was essentially independent from these soil characteristics.

For most elements, a limited number $(<10)$ of plant samples had a metal content much higher than the bulk of the data. In Table 1, maximum values are listed. Selected plots where outliers were included, are shown in Fig. 4. These outliers were, without exception, encountered on soils low in clay and organic carbon contents.

Scatterplots of the different elements one against another reveal that these high metal contents were not found in the same plants for the different elements (Fig. 5). Rather, each cloud of data points exhibits an L-shape, indicating that metal contents varied independently between the plant samples. As the plant samples were not washed, metals adhering to the outside of the plant material were also analysed. This, however, cannot be attributed as a major cause of the high plant contents found: high plant concentrations would have to be encountered irrespective of the clay or organic carbon content. In our data, high plant concentrations were found exclusively for soils, low in clay and organic carbon. Rather, similar as for $\mathrm{Zn}$ and $\mathrm{Mn}$, it may be concluded that a high uptake of these metals - more occasionally - can occur on soils, low in clay and organic carbon.

\subsection{Influence of soil $p H$}

The soil $\mathrm{pH}$ is known to be an important parameter in controlling metal availability and hence uptake by plants [3] [15]. In our field data, for none of the elements studied was there a noticeable relation between the plant concentrations and soil pH (Fig. 2 for $\mathrm{Zn}$ and Fig. 6). In the field, soil $\mathrm{pH}$ is one of numerous factors that may control the uptake of metals by an individual plant. These factors not only include the soil physical and chemical parameters, or plant species, but may also include the weather conditions during growth, humidity and temperature regimes, etc.

In summary, the data presented suggest that bulk soil characteristics as clay, organic carbon content, soil $\mathrm{pH}, \mathrm{CEC}$ and total soil metal content have no decisive influence on the final metal concentration in the plant. However, higher levels of clay and/or organic carbon prevent a high uptake of metals by the plant from occurring.

\subsection{Variability of plant metal contents}

Prediction of plant metal concentrations from bulk soil characteristics does not seem an obvious task. We tried to construct multiple regression models by means of stepwise inclusion of the various soil parameters and transformations thereof. Determination coefficients generally were lower than 0.1 . The data presented do however allow to predict an expected range for the concentration of metals in plants that, in particular for $\mathrm{Zn}$ and $\mathrm{Mn}$, may vary as a function of soil parameters. 
The soils were categorised in groups according to the sum of their clay and organic carbon contents, weighed by a factor. From the scatterplots of Zn (Fig. 2) and Mn (Fig. 3) versus clay content and organic carbon content in the soil, it is observed that the variability in plant metal content decreased for a clay content higher than $10 \%$ and an organic carbon content higher than 3\%. Organic clay therefore was weighed by a factor 3 and organic carbon by 10 . The soils were grouped into 4 categories, defined by $(3 \times \%$ clay $+10 \times \%$ organic carbon $)$ threshold values of 20,40, and 60 . For soils containing no clay, these values correspond with an organic matter content of 2, 4 and $6 \%$. For each of the categories, percentile values were calculated that are listed in Table 2. These tables can be used to estimate metal content ranges in stinging nettle as a function of clay and organic matter content of the soil.

As already clear from the scatterplots, the concentration ranges of $\mathrm{Zn}$ and $\mathrm{Mn}$ decreased with increasing $(3 \times \%$ clay $+10 \times \%$ organic carbon $)$ in the soil. For the other elements, the plant concentrations and their ranges were independent of these soil characteristics. Outlying values were retained in the calculations but, because of their small count, had a very small influence the calculation of percentiles.

\section{Summary and conclusions}

The relation between soil parameters - clay content, organic carbon content, $\mathrm{pH}$, cation exchange capacity and soil total metal content - and concentrations of metals in stinging nettle in the field was studied. Plant metal concentrations are influenced by numerous factors. The data presented suggest that bulk soil characteristics as clay, organic carbon content, soil $\mathrm{pH}$, CEC and total soil metal content have no decisive influence on the actual metal concentration in a plant. However, higher levels of clay and organic carbon clearly prevent a high uptake of metals by the plant from occurring.

For $\mathrm{Zn}$ and $\mathrm{Mn}$, larger variations in plant metal contents are expected for soils low in clay, organic $\mathrm{C}$ and $\mathrm{CEC}$. For these elements, an expected range for metal contents in a plant may be predicted from bulk soil characteristics. On their own, these soil parameters do not constitute sufficient information for a precise prediction of plants metal contents in the field.

\section{Acknowledgements}

The authors wish to thank Prof. E. Van Ranst and his co-workers, L. Vanmechelen and R. Groenemans, for the use of the soil database AARDEWERK and the geostatistical estimation of the clay contents.

\section{References}

1 A. Cottenie, Behaviour and biological importance of heavy metals in the soil. Chimia, 34 (1980) 344-345.

2 A Kabata-Pendias and H. Pendias, Trace elements in soils and plants. CRC Press, Boca Raton, Florida, 1984.

3 D. C. Adriano, Trace elements in the terrestrial environment. Springer-Verlag, New York, 1986.

4 H. Barth and P. L'Hermite (Ed.), Commission of the European Communities. Scientific basis for soil protection in the European Community. Elsevier, Amsterdam, 1987.

5 EPA. Integrated risk information system (IRIS). EPA, Washington, 1992. 
6 W. Veerkamp, The concepts of HESP, reference manual - Human exposure to soil pollutants, version 2.10a. SHELL Internationale Petroleum Maatschappij, Den Haag, 1994.

7 A Cottenie and M. Verloo, Chemische karakterisatie van bodemverontreiniging. Universiteit Gent, Gent, 1985.

8 L. E. Allison, Organic carbon, in C. A. Black et al. (Ed.), Methods of soil analysis. Part 2. Chemical and microbiological properties. Agronomy Monograph 9 (2nd edition). ASA, Madison, Wisconsin, 1965, pp. 1367-1378.

9 A. Cottenie, M. Verloo, L. Kiekens, G. Velghe and R. Camerlynck, Chemical analysis of plants and soils. IWONL, Brussel, 1982.

10 D. Van Orshoven and D. Vandenbroucke, Handleiding bij AARDEWERK. Databestand van profielgegevens. IWONL, Brussel, 1993.

11 A. M. Ure, Methods of analysis for heavy metals in soils, in B. J. Alloway (Ed.), Heavy metals in soils. Blackie and Son, Glasgow, 1990, pp. 40-73.

12 N. Cavallaro, M. B. McBride, Zinc and copper sorption and fixation by an acid soil clay: effect of selective dissolutions. Soil Sci. Soc. Am. J., 48 (1984) 1050-1054.

13 M. B. McBride, Reactions controlling heavy metal solubility in soils, in R. A. Stewart (Ed.), Advances in Soil Science. Volume 10. Springer-Verlag, New York, 1984.

14 L. J. Evans, Chemistry of metal retention by soils. Environ. Sci. Technol., 23 (1989) 1046-1056.

15 B. J. Alloway and A. P. Jackson, The behaviour of heavy metals in sewage sludgeamended soils. Sci. Total Environ., 100 (1991) 151-176. 
Table 1

Summary statistics of the data studied

\begin{tabular}{|c|c|c|c|c|c|}
\hline Variable & Mean & Median & $\begin{array}{l}\text { Interquartile } \\
\text { range }\end{array}$ & Minimum & Maximum \\
\hline \multicolumn{6}{|l|}{ Soil characteristics } \\
\hline Clay content $(\%)$ & 7.0 & 4.9 & 5.2 & 0.1 & 53.8 \\
\hline Organic carbon $(\%)$ & 1.9 & 1.6 & 0.7 & 0.2 & 10.4 \\
\hline $\mathrm{pH}$ & 5.8 & 5.8 & 1.0 & 4.0 & 8.1 \\
\hline $\mathrm{CEC}\left(\mathrm{cmol}_{\mathrm{c}} \mathrm{kg}^{-1}\right)$ & 9.9 & 7.9 & 3.1 & 2.7 & 62.1 \\
\hline \multicolumn{6}{|c|}{ Soil metal contents ( $\mathrm{mg} \mathrm{kg}^{-1} d r y$ soil) } \\
\hline $\mathrm{Cd}$ & 0.54 & 0.16 & 0.41 & 0.04 & 13.8 \\
\hline Co & 0.6 & 0.1 & 0.5 & 0.0 & 11.5 \\
\hline $\mathrm{Cr}$ & 37.6 & 25.0 & 13.9 & 5.2 & 615.6 \\
\hline $\mathrm{Cu}$ & 11.6 & 9.7 & 4.6 & 1.7 & 133.2 \\
\hline $\mathrm{Fe}$ & 1268 & 896 & 900 & 0 & 10506 \\
\hline Mn & 98 & 71 & 61 & 0.6 & 792 \\
\hline $\mathrm{Ni}$ & 6.1 & 5.2 & 1.4 & 4.5 & 40 \\
\hline $\mathrm{Pb}$ & 28 & 21 & 17 & 0.0 & 244 \\
\hline $\mathrm{Zn}$ & 54 & 34 & 13.4 & 14.9 & 1817 \\
\hline \multicolumn{6}{|c|}{ Plant metal contents ( $\mathrm{mg} \mathrm{kg}^{-1}$ dry matter) } \\
\hline $\mathrm{Cd}$ & 0.43 & 0.34 & 0.20 & 0.03 & 9.26 \\
\hline Co & 0.8 & 0.8 & 0.4 & 0.0 & 8.3 \\
\hline $\mathrm{Cr}$ & 6.6 & 5.7 & 2.7 & 0.0 & 180 \\
\hline $\mathrm{Cu}$ & 14.0 & 9.5 & 4.7 & 2.2 & 841 \\
\hline $\mathrm{Fe}$ & 432 & 370 & 216 & 6.1 & 2037 \\
\hline $\mathrm{Mn}$ & 291 & 199 & 258 & 4.9 & 3302 \\
\hline $\mathrm{Ni}$ & 9.1 & 9.0 & 2.9 & 0.0 & 97 \\
\hline $\mathrm{Pb}$ & 34 & 33 & 19 & 0 & 357 \\
\hline $\mathrm{Zn}$ & 113 & 83 & 82 & 23 & 532 \\
\hline
\end{tabular}


Table 2

Percentile values $(10,50$ and $90 \%)$ of plant metal concentrations $(\mathrm{mg} / \mathrm{kg} \mathrm{DM})$ as a function of $(3 \times \%$ clay $+10 \times \%$ organic $C)$ content in the soil

\begin{tabular}{|c|c|c|c|c|c|}
\hline \multirow[b]{2}{*}{ Element } & \multirow[b]{2}{*}{$\begin{array}{c}\text { Percentil } \\
\mathrm{e}\end{array}$} & \multicolumn{4}{|c|}{ Class $^{\mathrm{a}}$} \\
\hline & & 1 & 2 & 3 & 4 \\
\hline \multirow[t]{3}{*}{$\mathrm{Cd}$} & 10 & 0.15 & 0.14 & 0.18 & 0.07 \\
\hline & 50 & 0.25 & 0.34 & 0.40 & 0.33 \\
\hline & 90 & 0.47 & 0.48 & 0.49 & 0.51 \\
\hline \multirow[t]{3}{*}{ Co } & 10 & 0.11 & 0.27 & 0.36 & 0.00 \\
\hline & 50 & 0.69 & 0.80 & 0.86 & 0.66 \\
\hline & 90 & 1.33 & 1.22 & 1.11 & 0.94 \\
\hline \multirow[t]{3}{*}{$\mathrm{Cr}$} & 10 & 3.0 & 3.5 & 3.4 & 1.3 \\
\hline & 50 & 5.5 & 5.6 & 7.1 & 4.6 \\
\hline & 90 & 9.6 & 8.8 & 11.5 & 7.4 \\
\hline \multirow[t]{3}{*}{$\mathrm{Cu}$} & 10 & 4.9 & 5.4 & 7.8 & 5.4 \\
\hline & 50 & 8.7 & 8.9 & 12.9 & 10.1 \\
\hline & 90 & 13.3 & 14.4 & 18.4 & 22.7 \\
\hline \multirow[t]{3}{*}{$\mathrm{Fe}$} & 10 & 243 & 228 & 223 & 182 \\
\hline & 50 & 337 & 380 & 380 & 325 \\
\hline & 90 & 606 & 699 & 1079 & 1061 \\
\hline \multirow[t]{3}{*}{$\mathrm{Mn}$} & 10 & 69 & 76 & 49 & 32 \\
\hline & 50 & 224 & 231 & 157 & 78 \\
\hline & 90 & 820 & 727 & 300 & 275 \\
\hline \multirow[t]{3}{*}{$\mathrm{Ni}$} & 10 & 4.7 & 5.4 & 6.3 & 2.5 \\
\hline & 50 & 7.9 & 9.1 & 9.7 & 7.5 \\
\hline & 90 & 11.3 & 11.6 & 12.4 & 10.9 \\
\hline \multirow[t]{3}{*}{$\mathrm{Pb}$} & 10 & 4.9 & 8.2 & 14.5 & 0.0 \\
\hline & 50 & 28.5 & 32.9 & 39.3 & 33.2 \\
\hline & 90 & 52.4 & 51.3 & 54.0 & 92.4 \\
\hline \multirow[t]{3}{*}{$\mathrm{Zn}$} & 10 & 44 & 46 & 46 & 35 \\
\hline & 50 & 82 & 95 & 69 & 54 \\
\hline & 90 & 336 & 251 & 159 & 118 \\
\hline
\end{tabular}

${ }^{a}$ Class: the soils were classified according to $(3 \times \%$ clay $+10 \times \%$ organic carbon $)<20$ (class 1$) ; 20-40$ (class 2); 40-60 (class 3); >60 (class 4) 
Fig. 1. Map of the sampled area in Belgium with indication of the sampling points Fig. 2. Plant zinc concentration in relation to soil parameters. Datapoints are marked according to $(3 \times \%$ clay $+10 \times \%$ organic carbon $)$ in the corresponding soil.

Fig. 3. Plant metal concentrations in relation to clay content. Datapoints are marked according to $(3 \times \%$ clay $+10 \times \%$ organic carbon $)$ in the corresponding soil.

Fig. 4. Plant concentrations of $\mathrm{Cd}$ and $\mathrm{Co}$ in relation to clay content, with inclusion of outliers Fig. 5. Matrix of scatterplots of element concentrations in the plant

Fig. 6. Plant metal concentrations in relation to soil $\mathrm{pH}\left(1: 5\right.$ in $\left.\mathrm{H}_{2} \mathrm{O}\right)$. Datapoints are marked according to $(3 \times \%$ clay $+10 \times \%$ organic carbon $)$ in the corresponding soil. 


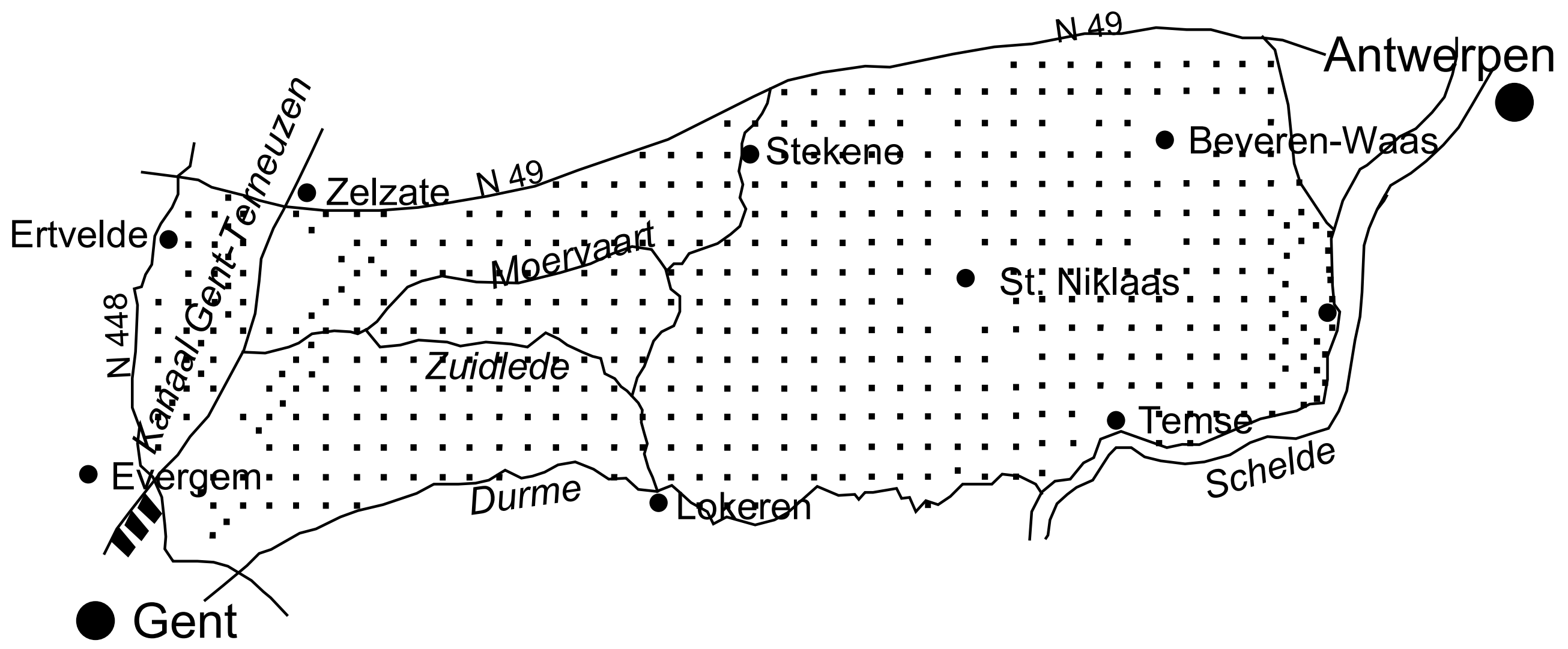

Fig. 1. Map of the sampled area in Belgium with indication of the sampling points 

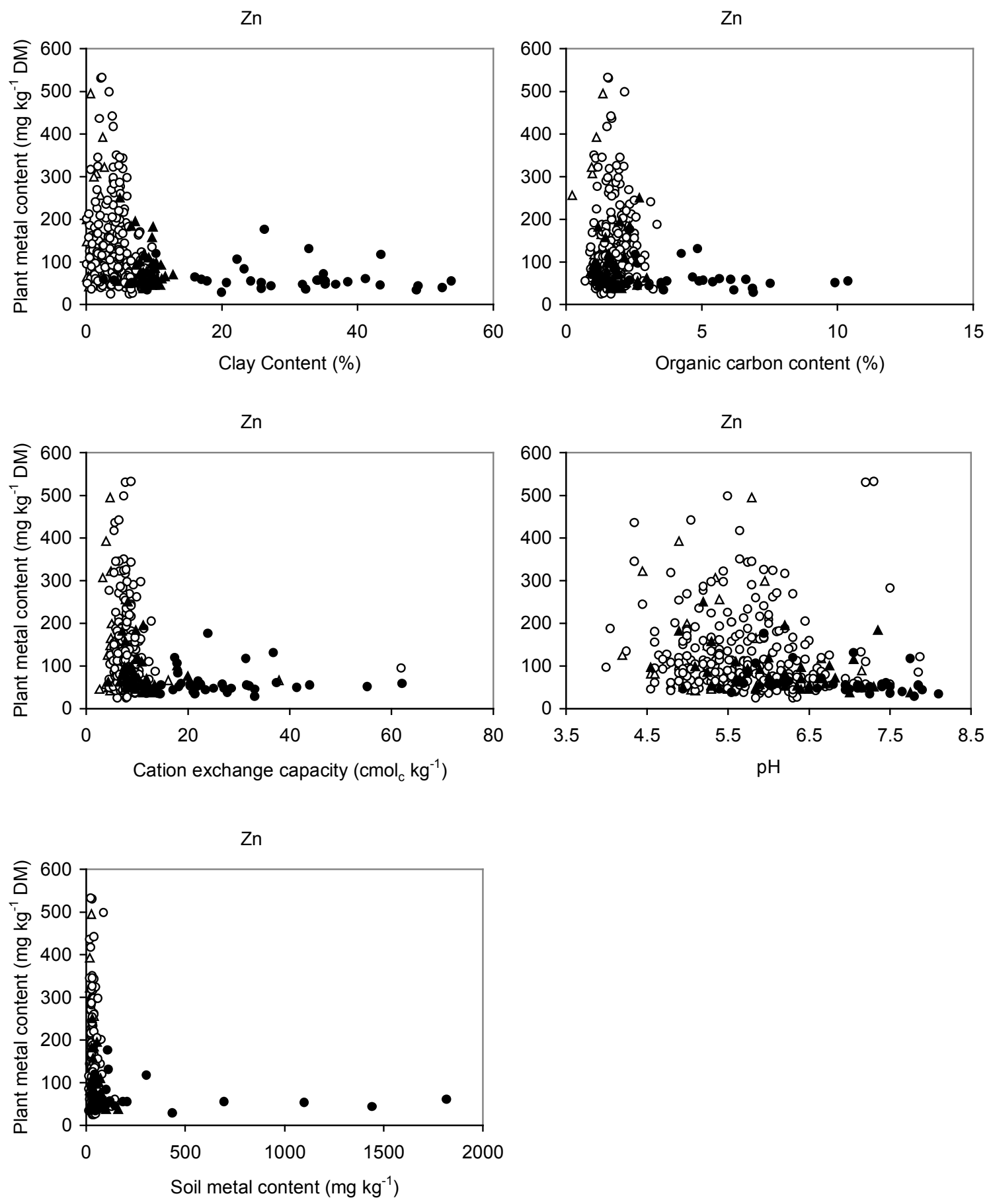

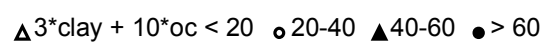

Fig. 2. Plant zinc concentration in relation to soil parameters. Datapoints are marked according to $(3 \times \%$ clay $+10 \times \%$ organic carbon $)$ in the corresponding soil. 
$\mathrm{Cd}$

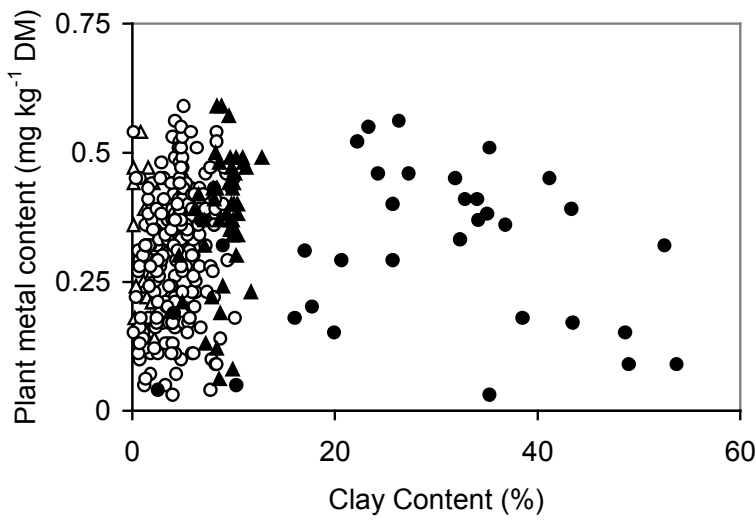

$\mathrm{Cu}$

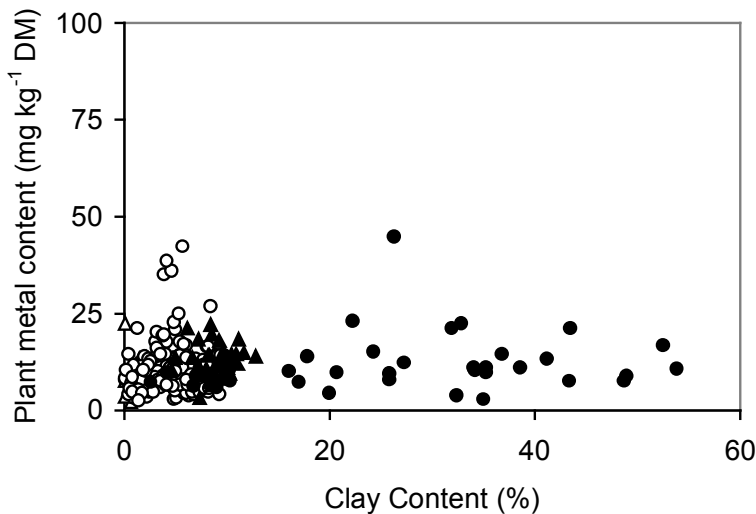

$\mathrm{Pb}$

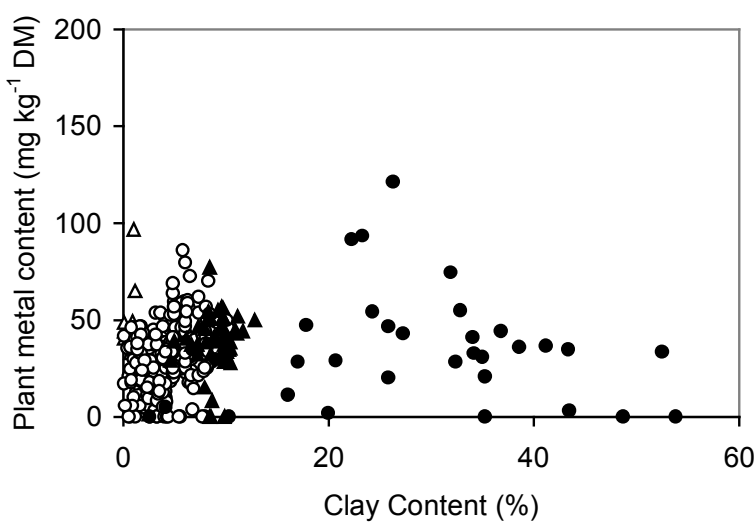

$\mathrm{Cr}$

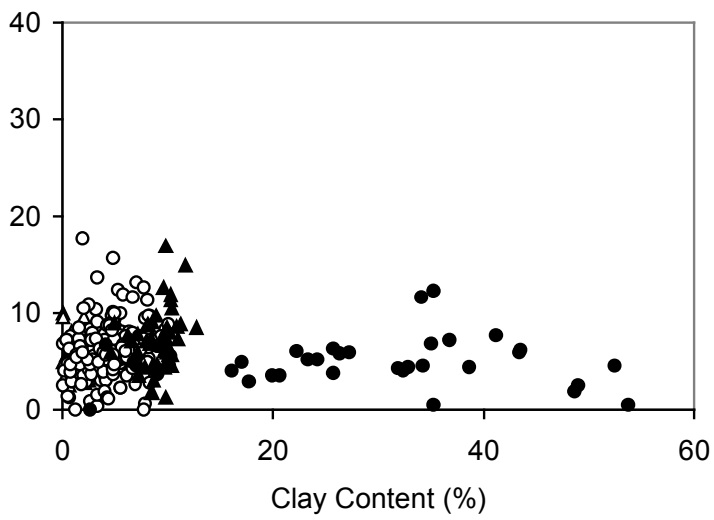

$\mathrm{Ni}$

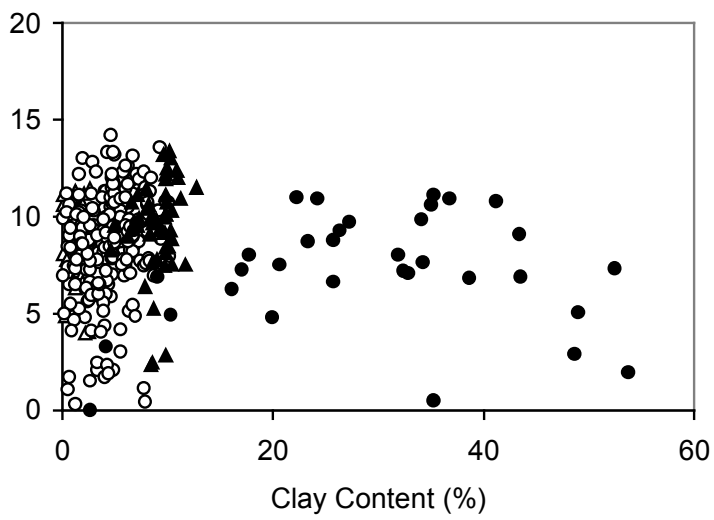

$\mathrm{Mn}$

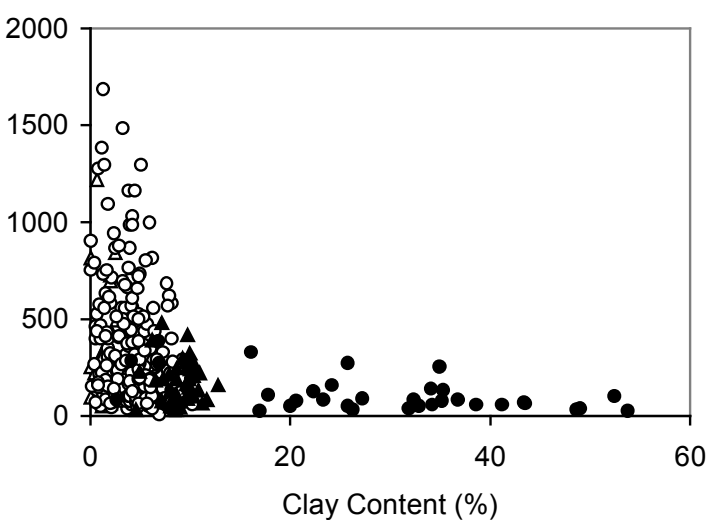

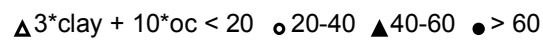

Fig. 3. Plant metal concentrations in relation to clay content. Datapoints are marked according to $(3 \times \%$ clay $+10 \times \%$ organic carbon $)$ in the corresponding soil. 
$\mathrm{Cd}$

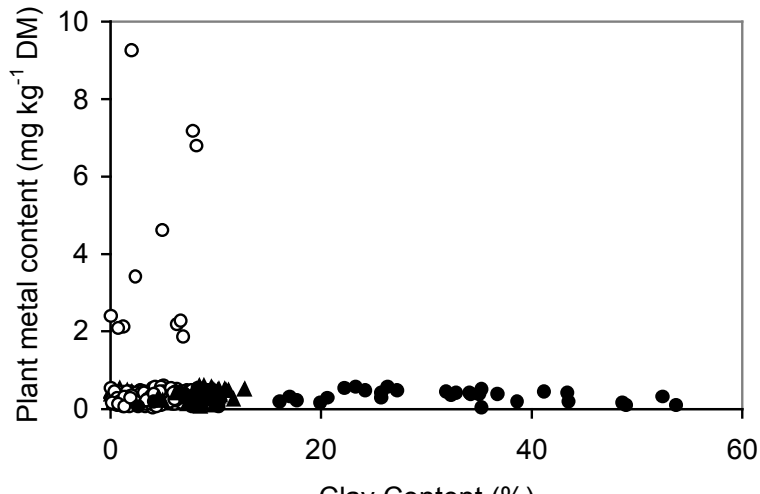

Clay Content (\%)
Co

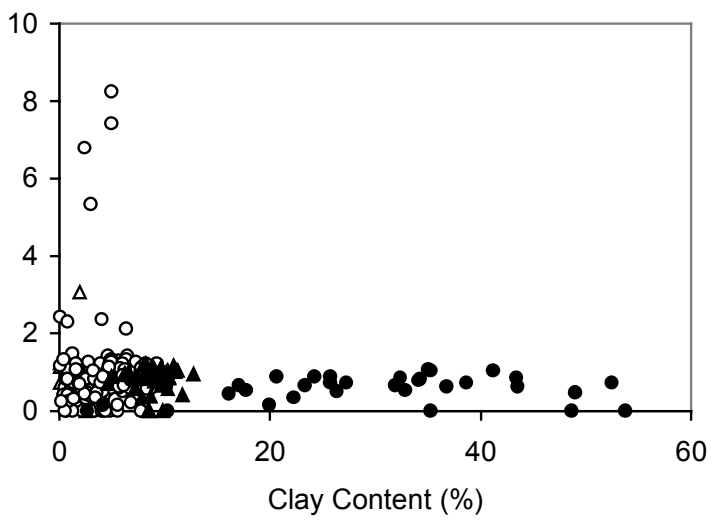

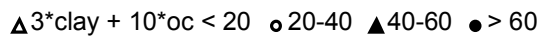

Fig. 4. Plant concentrations of $\mathrm{Cd}$ and $\mathrm{Co}$ in relation to clay content, with inclusion of outliers 


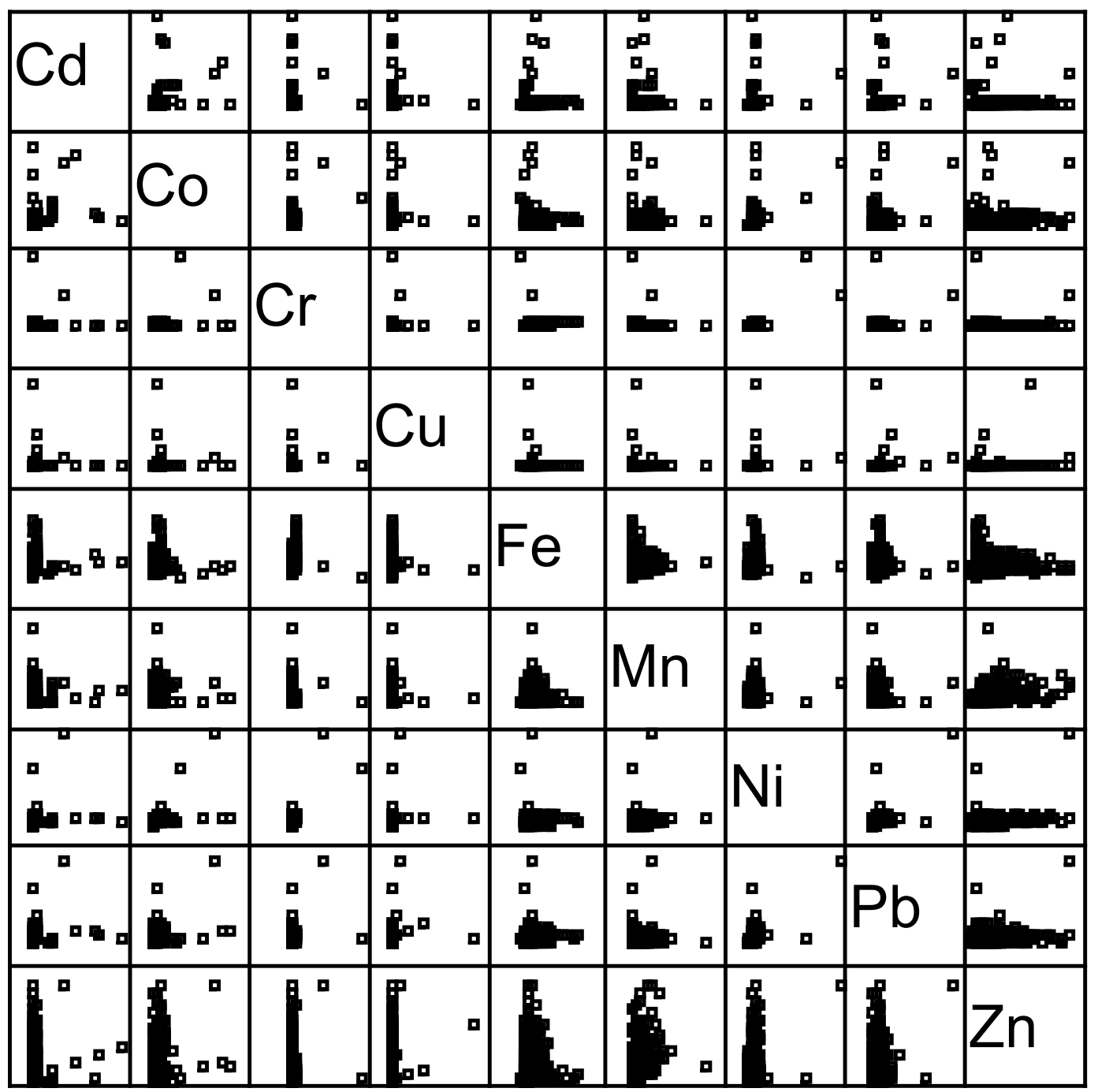

Fig. 5. Matrix of scatterplots of element concentrations in the plant 
$\mathrm{Cd}$

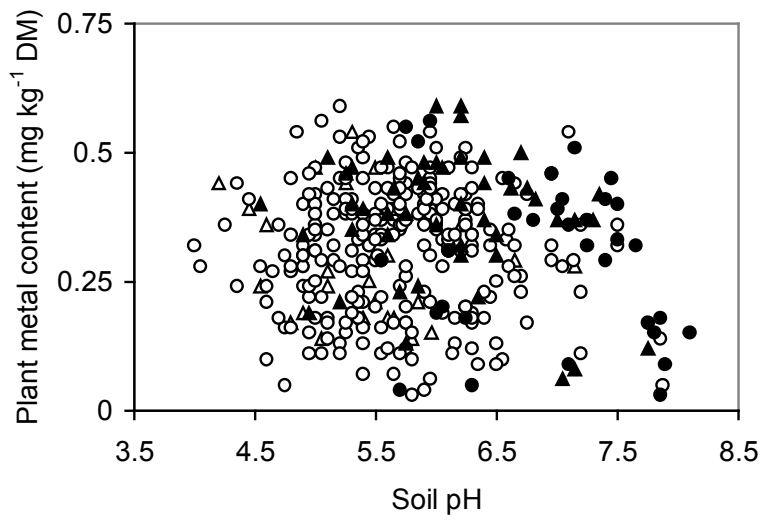

$\mathrm{Cu}$

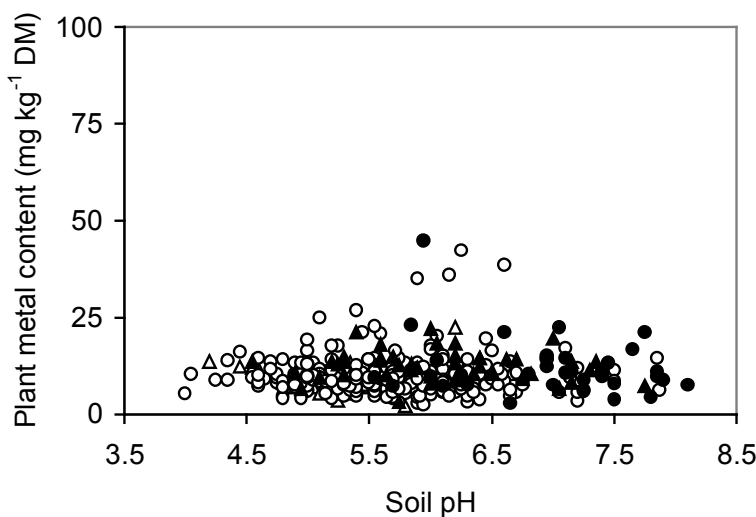

$\mathrm{Mn}$

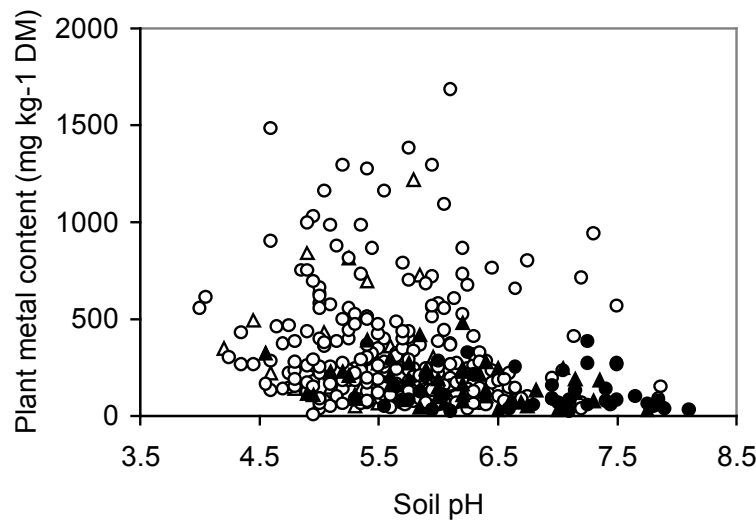

$\mathrm{Cr}$

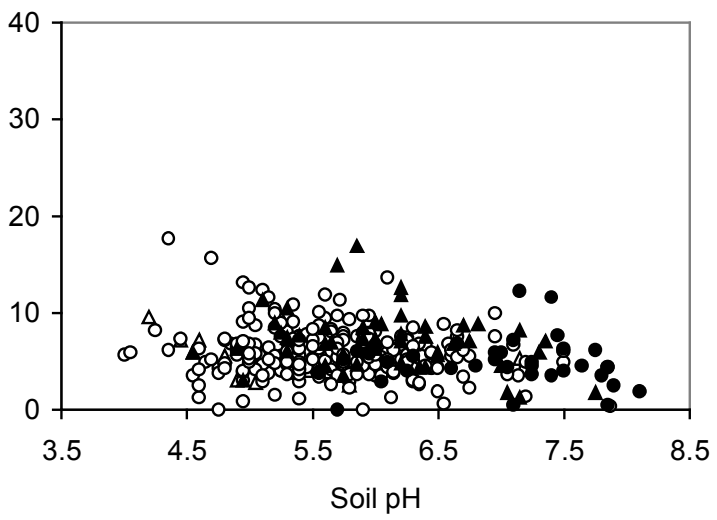

$\mathrm{Ni}$

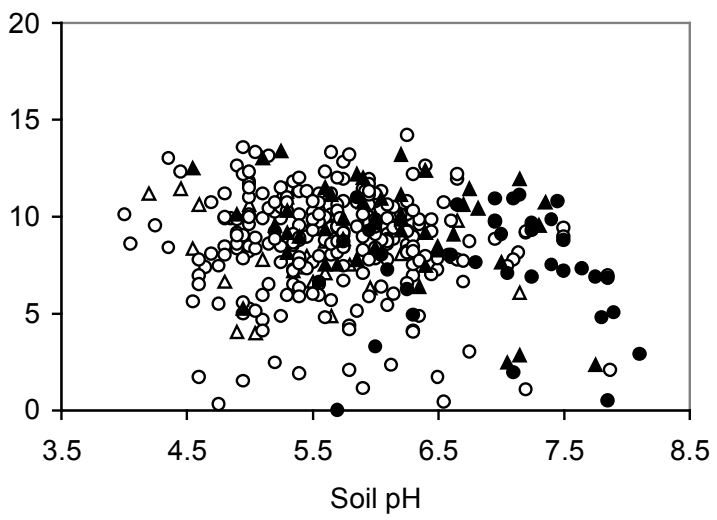

$\mathrm{Pb}$

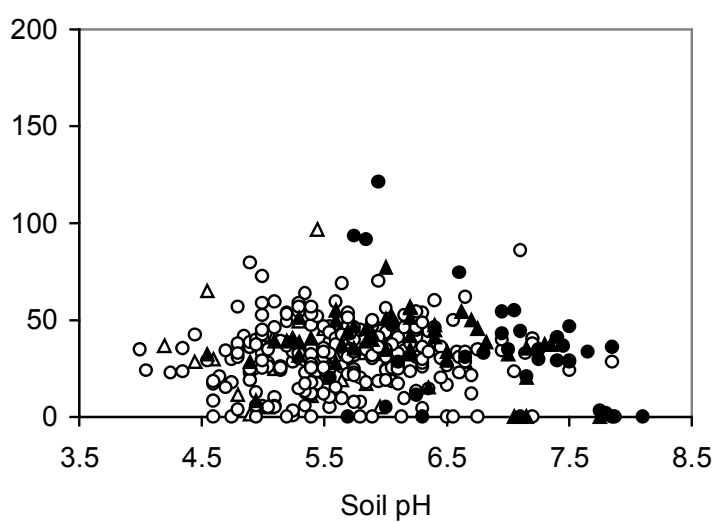

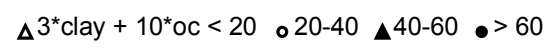

Fig. 6. Plant metal concentrations in relation to soil $\mathrm{pH}\left(1: 5\right.$ in $\left.\mathrm{H}_{2} \mathrm{O}\right)$. Datapoints are marked according to $(3 \times \%$ clay $+10 \times \%$ organic carbon $)$ in the corresponding soil. 